\title{
Metaphor and Metonymy in Word Formation
}

\author{
(Metáfora e Metonímia na Formação de Palavras)
}

Margarida BASILIO

(Pontifícia Universidade Católica do Rio de Janeiro)

\begin{abstract}
This work investigates the relevance of analogy, metonymy and metaphor in word formation patterns and their products. Initially, the semantic side of proportional analogy in morphological restructuring is analyzed. The work then concentrates on the role of metonymy in the formation of instrumentals and agent nouns. The last part of the work is dedicated to the role of metaphor in compounding. The main point of the paper is to show bow metaphor is fundamental to the constitution of the lexicon and, consequently, how unfortunate for the discussion of metaphor in language is the relative disregard to word-formation processes.
\end{abstract}

KEY-WORDS: analogy, metaphor, metonymy, word-formation.

RESUMO: Este trabalho investiga a relevância de padrões analógicos, metonímia e metáfora em processos de formaşão de palavras e seus produtos. Aborda-se inicialmente a face semântica do mecanismo de analogia proporcional no fenômeno de re-estruturação morfológica. Em seguida, o trabalho focaliza o papel da metonímia na formação de nomes de agente e instrumentais. A parte final do trabalho é dedicada ao papel da metáfora em processos de composição. O principal objetivo do trabalho é mostrar como a metáfora é fundamental para a constituição do léxico e, consequentemente, quão lamentável é o fato de que raramente processos de formação de palavras são levados em conta na discussão sobre a metáfora na linguagem.

PALAVRAS-CHAVE: analogia, metáfora, metonímia, formaşão de palavras

\section{Introduction}

This work investigates analogy, metonymy and metaphor in word formation patterns. In the first part of the work I analyze the role of analogy in some historical and recent cases of morphological restructuring, in English

D.E.L.T.A., 22:EsPeCIAL, 2006 (67-80) 
and Brazilian Portuguese. In the second part, I show the relevance of metonymy in agent and instrumental noun formation. The final part is dedicated to metaphor in compounding. My main goal is to show how fundamental metaphor and metonymy are for word-formation and, consequently, how unfortunate is the relative disregard to word-formation processes in the discussion of metaphor in language.

From a cognitive point of view, the lexicon can be initially defined as a large set of symbolic forms, that is, forms associated with meanings or forms which evoque meanings. Given their role in utterance construction, these forms are as flexible to meaning associations and use as colors may change depending on the color structure of a painting or the focus and intensity of light. Utterances we produce to communicate with each other have both meaningful and grammatical aspects, forming very complex patterns, from which new structure can emerge.

The lexicon has to expand because our communication and expression needs are constantly changing, mostly expanding, both in the individual and in the social level; word-formation patterns optimize lexical expansion. Here, I will explore the relevance of analogy, metaphor and metonymy in word formation and argue that they are central to the arsenal of strategies which enhance lexical efficiency.

\section{Analogy, metonymy and metaphor: some basic notions}

Even though our main concern here is not to discuss the highly controversial notions of analogy, metonymy and metaphor in the field of Semantics or in Cognitive Linguistics, some remarks are in order, so as to acquaint the reader as to the notions I will refer to in the following sections. ${ }^{1}$

The term analogy has been used in classical linguistic texts in the area of sound change. In order to maintain the deterministic character of sound change laws, so-called neo grammarians established some conditions under which one could admit changes not predicted by phonetic laws; analogy was one of those conditions. For instance, we find bonor as an alternative form for honos in Latin by effect of analogical change: intervocalic $s$ rhotacism results in intervocalic $r$ forms, from which the new form honor

\footnotetext{
1 My thanks to the anonymous referee who made that fundamental remark to me.
} 
is extracted. ${ }^{2}$ In this sense, analogy can be defined as a change made in a linguistic form by influence of another form in the same paradigm.

In philosophy, analogy is a point in relation to which something is close to something else. So, for instance, one can say in Descriptive Linguistics that the relation between morphemes and alomorphs is analogous to the relation between phonemes and allophones. As analogy refers to a point of similarity, the distinction between metaphor and analogy is a concern in philosophical discussion. ${ }^{3}$ In a more restrictive situation, that of the discussion of the nature of productive morphological mechanisms, de Saussure (1916) suggests that in language novel words can come from analogical proportion. ${ }^{4}$ On de Saussure's view, "forms that we see as analogicaly created actually existed all along, as potentialities of the system" (Anderson 1992:367). Here, in section 2. below, I am basically referring to the notion of proportional analogy in morphological change, but I also point out that some changes occur both by semantic analogy, in the sense of structural similarity, and morphological proportional analogy, as described in de Saussure's Cours.

The concept of metonymy has been intensely discussed nowadays, in its redefinition under a conceptual structure approach (see, for instance, Lakoff 1987, Langacker 1987, Barcelona 2003, Panther \&Radden 1999, etc.). However, almost always the focus is in the question of pragmatic inferences in speech. Studies on the role of metonymy in lexical processes are rare, ${ }^{5}$ as only now metaphorical and metonymic processes are being investigated as grammatical mechanisms rather than utterance phenomena.

Under a conceptual view of metonymy (Radden and Kovecses 1999), the metonymic process consists in mentally accessing one conceptual entity (the target) by means of another entity (the vehicle), as in the always quoted examples of places standing for agents, and so on. Metonymy turns out to be a fundamental instrument for the efficiency of the lexicon as a symbol

\footnotetext{
2 The same phenomenon would be today called "paradigmatic pressure"

3 For a short but very informative commentary on notions of analogy in different fields, see Lahiri 2000 .

4 In the mathematical sense, where "analogy" corresponds to a similarity in relationships which are proportional.

5 The only exception I am acquainted with is Panther\&Thornburg 2001, 2002, where the authors discuss the concept in relation to -er nominals in English.
} 
storage system:as we can mentally access one conceptual entity by means of another, it is possible to store only one conceptual entity instead of two or more partially connected entities. This mechanism, together with the notion of metonymic models (Lakoff 1987, Chapter 5) constitutes a relevant word-formation strategy, which I approach in section 3 below.

Traditional approaches to metaphor consider it as a figure of language, that is, a linguistic phenomenon; the first and unavoidable reference is Aristotle's conception of metaphor as an implicit comparison. Metaphor was somewhat left aside as a topic of discussion in Linguistics, given the influence of generative grammar. More recently, with the development of discourse studies and pragmatics, as well as the emergence of Cognitive Linguistics, the interest in metaphor is exponentially growing. In these new perspectives, the focus is mainly on metaphor as a conceptual and all pervasive phenomenon rather than a literary mechanism.

Some of the main issues we find in this new phase of the literature on metaphor are: (a) the distinction between literal/metaphorical sense of words and sentences; (b) the linguistic/conceptual character of metaphors; (c) the metaphorical meaning of words/speakers; (d) the function of metaphors.

The fact that the lexicon is not a matter of consideration in most of Cognitive Linguistics, Pragmatics and discourse studies makes it difficult for us to situate a concept of metaphor in the current discussion; the main point of this paper is to point out this problem, namely, the fact that most current discussion on metaphor disregards metaphor in words.

As we defined the lexicon as a large set of extremely flexible symbolic forms, our vision of the lexicon includes meaning flexibility as a inherent quality of the lexicon. Consequently, we cannot spouse Searle's view, according to which "sentences and words have only the meanings that they have. Strictly speaking, whenever we talk about the metaphorical meaning of a word, expression or sentence, we are talking about what a speaker might utter it to mean, in a way that departs from what the word, expression or sentence actually means. We are, therefore, talking about possible speaker's intentions"(1993:84). ${ }^{6}$ Searle thus treats metaphor as a

\footnotetext{
6 In fact, this is a good example for the problems resulting from the disregard for the lexicon. As compounds are in the midway between words and utterances, they have elements of each, which makes them a good field of analysis for metaphor properties.
} 
pragmatic phenomenon. I believe the data we find in compounds show clearly that this position is too restrict.

On the other hand, word-formation is viewed here as a tool related to lexical expansion, both in the individual and the general level. Thus, metaphor can be viewed as a cognitive instrument; this view is shared by Lakoffs theory of metaphor, both in the sense of its conceptual character and in the sense of economic patterning. But maybe the most important concept we can verify in metaphoric compounds is the idea that metaphors afford different ways of perceiving the world, defended by Schon (1993), among others.

Summarizing, our concept of metaphor, to be assumed in section 4 below, is that (a) there exists a distinction between literal and metaphorical meaning, even if it is not easy to distinguish them in all cases; (b) metaphorical compounds are both linguistic and conceptual phenomena; (c) metaphorical compounds are related to word meanings, as opposed to speaker's meanings; and (d) metaphors have both rhetorical and cognitive functions in the lexicon. As for the issue of similarity, I assume that metaphors in word-formation are based on conceptualized similarity, with the proviso that "conceptualized" encompasses recognized, revealed, abstracted and even induced similarities. ${ }^{7}$ Those can be shown either in proportional structures or in frames which may involve linguistic and encyclopedic knowledge.

\section{Analogy in word formation and morphological restructuring}

I have argued in a previous paper (Basilio, 1997) that analogical patterns (De Saussure, 1916, Anderson 1992) might provide a better account for word formation than rules, which were then claimed to be mere statistic protocols of use for some kinds of patterning. Here, I bring three examples of the intricate relation between the morphological and the semantic side of analogy.

\footnotetext{
This position is convergent with Ortony(1993:343), who considers that proportional metaphors have essentially the same structure as similarity metaphors.
} 
The first case is a classical example of morphological restructuring. The expression Hamburger steak, denoting some specific kind of steak, namely, chopped sirloin, was reduced to Hamburger, maintaining the same reference. So, we have Hamburger denoting a hamburger steak. Now, hamburger, or chopped sirloin, is a filling for sandwiches. So, very soon, hamburger was short for a hamburger sandwich. The following step was the restructuring of the derived (bamburg)ert into the (tham).(burger)\} compound.

There is an interesting work of analogical patterns in this restructuring. The morphological restructuring is based on the coupling of two structures, a morphological one and an encyclopedic one. In the morphological structure, we have the [[specifier][specified]] relation of the two parts of a compound. The encyclopedic structure corresponds to a specific filling in a bread container. The bread container is common to sandwiches in general; the filling gives each sandwich its singularity. The restructuring was then based on the superposition of the structure of the sandwich to the structure of the compound, as shown in (1):

(1) [ [ Hamburg]er] 'chopped sirloin sandwich $\longrightarrow$ [[ham] [burger] ] [ specifier ] [specified]

From the last form, already restructured, we then derive other varieties such as cheeseburger, fishburger, chickenburger, etc.

The morphological restructuring of $\{$ (Hamburg\}er\} to $\{$ (ham) (burger $\})$ was not just morphological, but morphosemantic, or, more exactly, morphoencyclopedic. This case thus presents both aspects of analogy, the structural aspect, shown in the patterns of word formation; and the framesemantic aspect. I point out that there is only an evocation power in the filling/specifier part of the compounds: in the same way a hamburger is not made of ham, a cheeseburger is not made only with cheese, and so on. In other words, the paralellism is only structural.

I turn now to a more recent restructuring, which gave birth to the bound morpheme-gate, frequently used to produce compounds that refer to political scandals.

The scandal of Watergate is tied to the figure of Nixon and the event of his resignation. As is well known, Watergate is the name of a condominium in Washington. We thus have a clear case of metonymy, as the name of the place is used for reference to the scandal. 
The name Watergate is a compound. Since it is a proper name, the specific meaning of its parts is less relevant; but the [[specifier][specified]] semantic relationship of the compound maintains its relevance. As the name Watergate, as a whole, referred to Nixon's scandal, in a specifier/ specified relationship, the basis for the structural transference is clear: we have the reference (Nixon's scandal) adapting to the compound structure of the metonymic name (Watergate), as shown below:

(2) [[Water][gate $]$ 'Nixon's scandal' $\longrightarrow$ [[X] [gate $]$ ' 'X's scandal' specifier specified

From this reanalysis, we have new coinings, from Irangate, some years ago, to the more recent Enrongate. ${ }^{8}$

The next case, involving a derived word, is the coining of enxadachim 'hoer' from espadachim ‘swordsman' by the brazilian writer Guimarães Rosa. The coining can be clearly defined in terms of the following proportional analogy:

(3) espada: espadachim:: enxada:X $\mathrm{X}=$ enxadachim

In this case, the morphological proportional analogy evoques a frame analogy. Of crucial relevance here is the fact that espadachim is a hapax legomenon, and a totally transparent one: espada corresponds to sword and espadachim corresponds to swordsman, so that the sequence-achim is inequivocally assigned to "agent". But, most important of all, as the frame of the swordsman is glamourous, and the agent formation element is unique, the use of the unique construction with the substitution of espada 'sword' by enxada 'hoe' provoques, by analogy, the transfer of the glamour from the swordsman to the agricultural worker, which was the intention of the author.'

I will not proceed into a more detailed analysis of analogical patterns here, but I hope to have illustrated the interweaving of the morphological and the frame-semantic patterns involved in morphological restructuring and the creation of new morphemes.

\footnotetext{
8 And many others, both inside and outside U.S. Even brazilian scandals are sometimes referred to by the [[X][gate]] structure, where X stands for a Portuguese word.

9 This case could also be analyzed as a blend. In fact, a good number of blends in Portuguese are based on morphological patterns.
} 


\section{Metonymy in agent and instrumental noun formation}

I turn now to the analysis of metonymy and its role in derivational patterns of agent and instrumental noun formation. The examples to be discussed are from $\{(X) v$ dor $\} \mathrm{n},\{(X) v$ nte $\} \mathrm{n}$ and $\{(X)$ ista $\} \mathrm{n}$ lexical constructions in Brazilian Portuguese.

$\{(V\}-d o r\}) \cdot n$ deverbal agent nouns are frequently used in Portuguese to name someone for a professional activity represented by the verbal stem, as in (4);

(4) vendedor 'seller', zelador 'janitor', administrador 'administrator'

they are also used to form instrumentals, that is, nouns that name objects for their function, expressed in the verbal stem, as in (5)

(5) secador, liquidificador, refrigerador, computador hair dryer, mixer, refrigerator, computer

In Brazilian Portuguese, $\{V($ dor $\})$ instrumentals are mechanical, electrical or electronic, whereas chemical instrumentals are represented in $\{(V) n t e) n$ constructions, as in (6)

(6) adoçante, tranquilizante, fertilizante, desodorante sweetener, tranquilizer, fertilizer, deodorant

The morphological pattern for deverbal agent and instrumental noun formation is systematically connected to what Lakoff (1987) and Langacker (1987) call a metonymic model, as the products of these patterns systematically refer to human beings, objects and substances by their typical actions or functions.

According to Lakoff (1987), people frequently take a well-understood aspect of something and use it to stand either for the thing as a whole or for some other aspect or part of it, as in the frequently referred examples of places standing for institutions, such as Washington for the US Government or Brasilia for the Brazilian Government.

Professional agents constitute a significant part of $\{X-d o r\} \mathrm{n}$ agents in Portuguese. In these constructions, we have a cognitive model, that of the professional market, which establishes a structure of functions and categories for workers, as well as their labels. Workers are frequently categorized by $[V$-dor $] n$ constructions, where $\mathrm{V}$ stands for the most typical or relevant 
function among the many functions a worker performs in a given employment. So, we have in the construction of the agent noun a morphological pattern connected to a metonymic model.

Consider, for instance, the double function of universities and schools both as places for transmission of knowledge and research instruction and as immense bureaucracies that license and classify people for the job market. Teachers and professors do some teaching (and even some "professing") in schools and universities, but their time is more and more dedicated to tasks related to grading, administration and the like. And yet, in the job market, the society and the language, teachers are metonymically named for their teaching.

As for the $(V-d o r) \mathrm{n}$ instrumentals, we might say metonymy is of a different kind, as specific objects are referred to by their function, which could be fulfilled either by an agent or by a different kind of object, depending on the state of the corresponding technology. Consider, for instance, the instrumentals apagador 'eraser' and computador 'computer'.

In Brazilian Portuguese, apagador denotes an object used to erase blackboards. An apagador usually has a wooden handle and some industrialized compact flanel-like part, which absorbs the chalk. But the construction could also denote someone who has the function of erasing blackboards, or some other object or system with the erasing function. In the same way, the evolution of computers show us that instrumentals are good labels, in spite of the enormous changes in different aspects of the referred object. The fact that the $(V-d o r)$ n constructions usually label only one specific object constitutes a banal metonymy underlying instrumental formations in general.

As $(V-d o r) \mathrm{n}$ constructions denote both agents and instrumentals, we have a systematically polysemic situation: the morphological pattern $\{(\mathrm{V})$. dorf $\mathrm{n}$ provides reference for any $\mathrm{X}$ by what $\mathrm{X}$ does, which covers either people characterized by their actions or objects characterized by their functions. The characterization by action or function, however, is not predicted by linguistic structure, but by the socio-economically-based work and market structures.

In the case of $(V-n t e) \cdot n$ formations, the fact that the function expressed in the verbal base is performed specifically by chemical agents adds a special 
flavor to the metonymical process, as we can see in the question below, standardly used in a coffee serving situation:

(7) O que você prefere, açúcar ou adoçante?

What (do) you prefer, sugar or sweetener?

where the more natural substance represented by sugar is opposed to the more chemical sweetener.

Let us consider now $[X$-ist $\}$ n formations. Those can be either denominal agents, as in pianista 'pianist', specialists, as in linguista 'linguist', or people denoted by their beliefs or political, theoretical or ideological convictions, as in esquerdista 'leftist', cognitivista 'cognitivist', etc. The metonymic model is once again present, but in a different manner, as people are denoted not by their actions, but by the object of their actions, in the first two cases; and by the object of their convictions, in the third one.

A specially interesting case is provided by $(X-i s t) n$ constructions based on proper names, as Marxista 'marxist' or budista 'budist': people are denoted by their convictions; and those convictions are denoted by a proper name which emblematically stands for them.

Morphological patterns corresponding to agent and instrumental noun formation are not the only patterns to show a connection to metonymic models; on the contrary, the phenomenon is widespread in word-formation. I hope for the moment they were sufficient to show the relevance of metonymy in word formation patterns. I turn now to metaphor in compounding.

\section{Metaphor in Compounding}

Most compounding is done for naming or denoting purposes. The reasons we can have for naming are various, ranging from more objective to more subjective. So, it is not by coincidence that we find so frequently a great distance between the meaning of compounds and the meaning of their constituent parts. This partly derives from the fact that in compounding we put together two words, and words are fundamentally polysemic units. But this effect is also due to metaphor, as naming can be specially subjective sometimes. 
Things, people and events could be referred to by arbitrary labels. When we are dealing with thousands and thousands of data, however, regularity is a good technology, provided it is not absolute. So, naming by predication constitues a rather common process of lexical expansion, by means of which entities are given names which refer to their relevant specifying properties. So, for instance, doorman, though not entirely descriptive, evoques a frame which helps the speaker to catch and store the meaning of the compound.

But naming doesn't only provide labels to evoque points in frames; it also serves the purposes of predication.In fact, naming can be a much stronger form of predication, since it is a statement of fact, that is, something that cannot be denied. ${ }^{10}$ As a consequence, compounding may correspond to a strong rhetoric tool. Last but not least, poetic function permeates all language use; and the act of naming is a common circunstance in which poetic function does take place, be it humourous, lyric or whatever.

In order to illustrate metaphor in compounding, I will analyze here three compounds in Brazilian Portuguese, all based on the word olbo 'eye'.

Consider first the case of olho-de-sogra, where the sequence of words corresponds to English "mother-in-law's eye", but the compound names some kind of candy, frequently seen in children's or family parties. The candy is made with an open dried prune, involved in egg cream, so that the appearance of the whole evoques a very open big eye, as the eye of a submerged corpse. In this case, where the poetic function takes a more aggressive vein, the objective appearance is mixed up with cultural factors: these candies are home-made, they are made by women and they are served in family and children's parties; situations where the presence and cultural stigmatization of the figure of the mother-in-law are referred to in the name of the candy.

Consider next olbo-d'água, which has the same compound structure. Olho d'água ('eye-of-water') is used to name a small spring of water, mostly temporary. In this compound, the tear evoquing character of the geographic thing/event led us from the water to the eye for naming purposes. Thus we could say there would be here a metonymy rather than a metaphor. But, even if that happened to be the case, still the metonymy would come from

10 This is one reason why metaphor is so much stronger than comparisons. 
the metaphor: water springing from a point evoques tears, which leads to the eye-related naming of the accident.

In fact, olho d'água could be considered just as a metaphor focusing on a structural similarity: the event of water temporarily flowing from the earth is structurally similar to the event of tears temporarily flowing from our eyes. The compound is an interesting encapsulation of the structural similarity being used to name the thing/event via metonymy. Water flowing is an event, especially in this case where it is temporary; but it is not the event that is metonymically named by its source: the event is the base of the structural comparison, but what is named in the compound is the source; the word eye is chosen not by any direct similarity, but as the source of the flow of tears to which the temporary flow of water was compared. This is a clear case of the intricate interaction of tropes that Gibbs (1994: 449) refers to. ${ }^{11}$

Finally, let's take a look at olho-mágico 'magical eye' , a $\{(N) \cdot\{$ Adj\} $\}$. compound denoting a small orifice covered in unbreakable glass, which permits someone from the inside of an apartment house to see who is ringing the bell without being seen. The idea of invisibility is very much tied to the idea of magic, so that the set would combine the function of the eye with the magic of the invisibility. So, olbo mágico is a very objective metaphor, since eye can be defined as some orifice that permits seeing; and invisibility as a normal function is rightly predicated as magic. ${ }^{12}$

There is a further point in common in the compounds above, besides the use of the word olbo: the poetic function intermingles with the objective need to name things, be they candies, security devices or geographical accidents. In the three examples, we have a mechanism of naming by similarity or association. In other words, we have a way of using previously known elements to establish a connection and insert a new element in a network, so that it will be much more easily remembered.

\footnotetext{
11 Even though he doesn't mention the issue in relation to the lexicon.

12 Of course, this is only one of the many analyses that could be made; we could also think of metonymy, since the orifice in the door is for the eye; etc.
} 


\section{Final Remarks}

Approaching the lexicon from a cognitive point of view, we analyzed in this work the role of analogical patterns, metonymy and metaphor in word-formation. Word-formation patterns have the main function of optimizing lexical expansion, which means both providing the means for producing immediately recognizable, acceptable and interpretable new words and enhancing the conditions of permanence of these words in the long-term memory.

Examples of proportional analogy show how word-formation patterns can be used in unexpected ways, either expressively or in restructuring situations. The examples of agent and instrumental noun formation show that word-formation patterns systematically explore the metonymic use of some basic characteristic of something/someone for the denotation of the whole. Finally, the use of metaphor in compounding shows, say, that beautiful is useful: poetic function establishes a different plan in naming, so that the same basic element can be used in different labels; on the other hand, metaphors call attention, because of the necessary detour in meaning; and calling attention, as much as repetition, enhances the permanence of the item with its meaning in memory.

The lexicon always works in these ways, in the extremely flexible regularity of word-formation. The morphological part of these patterns, however, is just the tip of the iceberg. Here I began to explore the usually hidden semantic side of word-formation and its connections to morphological patterns in the constitution of the lexicon of Brazilian Portuguese.

I expect to have made it clear that analogy, metonymy and metaphor are largely used as functional mechanisms in word-formation. As the lexicon provides basic units both for language and thought and word-formation patterns are shown to be strongly involved with metaphor, metonymy and analogy, a better regard on the role of these tropes in word-formation is in order, if we want to have a more encompassing vision of metaphor in language and thought.

E-mail:marbas@centroin.com.br 


\section{REFERENCES}

Anderson, S. 1992. A-morphous Morphology. Cambridge: Cambridge University Press.

Barcelona, A. Ed. 2003. Metaphor and Metonymy at the Crossroads . A Cognitive Perspective. Berlin/New York: Mouton de Gruyter.

BASILIO, M. 1997. O princípio de analogia na constituição do léxico: regras são clichês lexicais. VEREDAS 1:9-21.

De Saussure, Ferdinand. 1916. Cours de Linguistique Générale. Paris: Payot.

GibBs, R. 1994. The Poetics of Mind: Figurative Thought, Language and Understanding. Cambridge: Cambridge University Press.

Lahiri, A. Ed. 2000. Analogy, Levelling, Markedness . Berlin: Mouton de Gruyter.

Lakoff, G. 1987. Women, Fire and Dangerous Things. Chicago/London: The University of Chicago Press.

LANGACKeR, R. 1987. Foundations of Cognitive Grammar. Volume I: Theoretical Pre-Requisites. Stanford: Stanford University Press.

Ortony, Andrew.Ed. 1993. Metaphor and Thought. $2^{\text {a }}$ edição. Cambridge: Cambridge University Press.

.1993. The Role of Similarity in similes and metaphors. In: Andrew Ortony. Ed. Metaphor and Thought. $2^{\mathrm{a}}$ edição. Cambridge: Cambridge University Press.

Panther, Klaus-Uwe e Gunter Radden. Eds.1999. Metonymy in Language and Thought. Amsterdam/Philadelphia: John Benjamins.

Panther, Klaus-Uwe e Linda Thornburg .2002. The roles of metaphor and metonymy in English -er nominals. In: René Dirven and Ralf Porings. Eds. Metaphor and Metonymy in Comparison and Contrast. Berlin/New York: Mouton de Gruyter. .2001. A Conceptual Analysis of English -er nominals. In: Martin Putz, Susanne Niemeier and René Dirven.Eds. Applied Cognitive Linguistics II: Language Pedagogy: 149-200. Berlin/New York: Mouton de Gruyter.

Radden, Gunter e Zoltán Kovecses. 1999. Towards a Theory of Metonymy. In: Klaus-Uwe Panther and Gunter Radden. Eds. Metonymy in Language and Thought. Amsterdam/Philadelphia: John Benjamins.

ScHON, Donald. 1993. Generative Metaphor: A prespective on problemsetting in social policy. In: Andrew OrTONy. Ed. Metaphor and Thought. $2^{\mathrm{a}}$ edição. Cambridge: Cambridge University Press.

Searle, John. 1993. Metaphor. In: Andrew Ortony. Ed. Metaphor and Thought. $2^{\mathrm{a}}$ edição. Cambridge: Cambridge University Press. 